\section{Revista de Literatura, História e Memória}

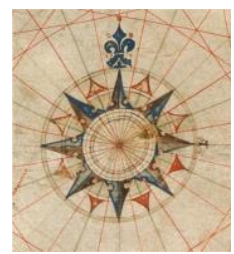

Dossiê: Feminismos e literaturas

ISSN 1983-1498

VOL. 17 - No 30 - 2021

U N I O E S T E / CA S C A V E L - p. 50-68

\title{
METAFICÇÃO HISTORIOGRÁFICA E GÊNERO: UMA LEITURA DE CARTA À RAINHA LOUCA, DE MARIA VALÉRIA REZENDE
}

Historiographic metafiction and gender: a reading of Carta à rainha louca, by Maria Valéria Rezende

Cindy Conceição Oliveira Costa ${ }^{1}$ Sebastião Alves Teixeira Lopes ${ }^{2}$

RESUMO: Este artigo objetiva analisar aspectos ligados aos estudos de metaficção historiográfica e gênero no romance Carta à rainha louca (2019), de forma a examinar, através da protagonistaescritora, uma visão feminina do Brasil do século XVIII. Apoiamonos nas teorias de Hutcheon (1991; 1984), Kause (2010), Scott (1995), Santos (2020), Del Priore (1994), entre outras. Como se sabe, a História foi por muito tempo narrada fundamentalmente sob uma perspectiva europeia, branca e masculina. Portanto, a metaficção historiográfica, ao se voltar para a História, encara-a de modo diferente, através de perspectivas ex-cêntricas, como a de uma mulher enclausurada e tida como louca, conforme apresentado no romance em apreço.

PALAVRAS-CHAVE: Maria Valéria Rezende; Carta à rainha louca; Metaficção historiográfica; Gênero; Crítica feminista.

ABSTRACT: This article aims to analyze aspects related to the studies of historiographical metafiction and gender in the novel Carta à rainha louca (2019), in order to examine, through the protagonist-writer, a female vision of Brazil in the 18th century. We rely on the theories of Hutcheon (1991; 1984), Krause (2010), Scott (1995), Santos (2020), Del Priore (1994), among others. As we know, History has for a long time been narrated fundamentally from a European, white and masculine perspective. Therefore, historiographical metafiction, when turning to History, sees it differently, through ex-centric perspectives, such as that of a cloistered and considered crazy woman, as presented in the novel mentioned.

KEYWORDS: Maria Valéria Rezende; Carta à rainha louca; Historiographic metafiction; Gender; Feminist criticism.

\section{INTRODUÇÃO}

Freira, feminista e escritora, Maria Valéria Rezende tem se destacado no cenário atual com uma produção vasta em temáticas, gêneros literários e também premiações. A autora,

\footnotetext{
${ }^{1}$ Mestranda em Literatura, Cultura e Sociedade pelo Programa de Pós-Graduação em Letras da Universidade Federal do Piauí (PPGEL-UFPI). Possui graduação em Letras/Português pela Universidade Estadual do Piauí (UESPI). É bolsista da CAPES e integrante do grupo de estudos em Literatura, Enunciação e Cultura (LECult) e do Grupo de Estudos em História e Literatura (GEHISLIT). E-mail: cindyoliveira87@gmail.com

2 Professor Titular da Universidade Federal do Piauí (UFPI), atuando no Programa de Pós-Graduação em Letras (PPGEL-UFPI). Doutor em Letras, área de concentração: Língua Inglesa e Literatura Inglesa e NorteAmericana, pela Universidade de São Paulo - USP (2002). Mestrado em Letras, Inglês e Literatura Correspondente, pela Universidade Federal de Santa Catarina - UFSC (1996). E-mail: slopes10@uol.com.br
} 
nascida em São Paulo em 1942 e radicada na Paraíba desde 1976, é graduada em Língua e Literatura Francesa e Pedagogia, possuindo também Mestrado em Sociologia, com pesquisa sobre a vida religiosa feminina no meio popular no Nordeste brasileiro. Em sua juventude, entrou para a Congregação de Nossa Senhora - Cônegas de Santo Agostinho, e através dela viajou por vários lugares do Brasil e do mundo. Nos anos 1960, também foi militante e participante da Juventude Estudantil Católica, movimento cristão de esquerda, demonstrando resistência ao regime autoritário instalado no país em 1964.

Dedicou-se à educação popular a partir de 1972, em São Paulo e, em seguida, no Nordeste brasileiro. Por sua atuação na educação e em trabalhos sociais, viajou por vários continentes, levando conhecimento aos menos favorecidos em uma linguagem mais acessível. De acordo com Piaceski (2019, p. 251), Maria Valéria Rezende é uma escritora sem fronteiras também em sua abordagem, “já que escreve para crianças e adultos, tanto poesia quanto prosa, abordando temas como o medo, a lealdade e as relações sociais, a violência contra a mulher, o analfabetismo, o trabalho escravo e braçal, a falta de dinheiro e a fome".

No período em que fazia as suas pesquisas para uma especialização sobre a vida religiosa das mulheres no período colonial brasileiro, há mais de 30 anos, encontrou no Arquivo Histórico Ultramarino, em Lisboa, a carta que serviria de inspiração para a escrita de seu romance mais recente, Carta à rainha louca (2019). A pesquisa culminou no artigo "A vida religiosa feminina no Brasil colonial", presente no livro A vida religiosa no Brasil (1983), organizado por Riolando Azzi. Nesse período, Maria Valéria Rezende iria ministrar um curso na Itália e resolveu passar por Portugal antes disso, e no Arquivo conseguiu pesquisar até mesmo em documentos não classificados.

Entre esse material, encontrou três cartas e um processo incompleto contra Isabel Maria, uma mulher que foi acusada de fundar um convento clandestino na região das Minas Novas (atual Minas Gerais). Das cartas, duas eram de padres enviados pelo arcebispo da Bahia, em 1753, para investigarem as acusações, uma vez que a Coroa portuguesa proibia a criação de conventos ou de qualquer instituição na colônia sem autorização.

Como a escritora conta, o primeiro padre explicava em sua carta que a casa administrada por Isabel Maria era apenas um local de acolhimento a mulheres brancas solteiras, que não possuíam familiares homens que lhes pudessem proteger. Enquanto o segundo afirmou se tratar de um convento clandestino, o que culminou na carta de Isabel Maria se defendendo, com certa ironia e um discurso teológico, na qual diz que jamais pediu "licença para viver piedosamente em sua própria casa, com suas parentas e amigas, pois não crê que seja necessário pedir e que ninguém lhe poderia negar o direito de viver 
virtuosamente" (AZZI; REZENDE, 1983, p. 42).

Carta à rainha louca, lançado em abril de 2019, trata-se de um romance epistolar que traz a trajetória da protagonista-escritora Isabel das Santas Virgens, escrita entre os anos de 1789 a 1792. A narrativa, guiada pelos fragmentos dos autos desse processo incompleto, surgiu da inquietação da autora em dar uma história e uma voz a essa mulher histórica, antes perdida nos documentos, bem como uma nova visão do período colonial brasileiro pouco conhecida: a de uma mulher, que, por não possuir dote, não poderia se casar e muito menos levar uma vida autônoma, o que era completamente fora da realidade feminina na época e por isso usou formas de resistência para conseguir sobreviver naquela realidade. Além disso, denunciava as mazelas que sofriam os que não possuíam um lugar na colônia ou que se encontravam em posições marginalizadas, como mulheres, pobres e escravizados.

Ao tratar sobre a ficção brasileira contemporânea, Schøllhammer (2009, p. 26-27) explica que com a abertura política e o processo de redemocratização do país surgiu "uma escrita psicológica que configura uma subjetividade em crise”. Conforme o autor, a literatura produzida no Brasil a partir da década de 1980 encontrou novos caminhos em seu processo literário, e esse período ficou conhecido como o da literatura pós-moderna. Muitos romances a partir desse período passaram a representar uma reescrita da memória nacional e a conter a presença da metaficção, tratando-se de uma literatura sobre literatura, uma ficção que discute a sua própria construção e reflete sobre como seus mecanismos afetam a percepção do que se conhece por real (SCHØLLHAMMER, 2009), como trataremos mais à frente.

A História foi por muito tempo narrada primordialmente sob uma perspectiva europeia, branca e masculina. Portanto, as metaficções historiográficas são narrativas ficcionais que se voltam para a História encarando-a de um modo diferente, através de perspectivas ex-cêntricas, no sentido de Hutcheon (1991), ou seja, fora do centro do discurso dominante, como a de uma mulher enclausurada e tida como louca, conforme apresentado no romance de Maria Valéria Rezende. Nesse sentido, o presente artigo teve como objetivo analisar alguns aspectos ligados aos estudos de metaficção historiográfica e gênero no romance Carta à rainha louca (2019), de forma a examinar, através da personagem Isabel, uma visão feminina do Brasil do século XVIII, mostrando essa espécie de não-lugar para mulheres como a protagonista-escritora.

\section{METAFICÇÃO HISTORIOGRÁFICA: UMA REVISÃO CRÍTICA DA HISTÓRIA}

A metaficção, apesar de ser um fenômeno muito recorrente nos estudos literários 
contemporâneos, é algo presente em diversas narrativas ocidentais, sendo difícil tentar apontar o início dessa tendência. A título de exemplo, Faria (2012) assinala Dom Quixote de la Mancha como o texto precursor dessas narrativas, apesar de ter por muito tempo sido classificado como um "antirromance", por sua posição paródica perante os romances de cavalaria, o que foi revisado após a emergência de estudos sobre a presença da metaficção em narrativas modernas. Assim, além de estar contida no protótipo do que se conhece por romance moderno no Ocidente, a metaficção pode ser entendida como uma das marcas da narrativa pós-moderna, pois, mesmo que exista há tanto tempo, foi apenas a partir de 1970 que se iniciou uma teorização mais notória sobre esse fenômeno.

No que se refere à sua conceituação, são diversos os teóricos que se debruçam para traçar as peculiaridades de tal estratégia narrativa, bem como foram diversas as suas denominações até chegar a certo consenso sobre o tema. Segundo Krause (2010), a metaficção é um fenômeno estético autorreferente no qual a ficção se duplifica dentro dela mesma, ou seja, falando de si ou contendo a si mesma. Nesse sentido, a metaficção "é uma ficção que não esconde que o é, mantendo o leitor consciente de estar lendo um relato ficcional, e não um relato da própria verdade" (KRAUSE, 2010, p. 42). Quando um(a) autor(a) utiliza esse recurso, deixa rastros para que o(a) leitor(a) apreenda as estratégias de criação literária, fazendo-o(a) refletir sobre o processo de escrita.

Para a pesquisadora canadense Linda Hutcheon (1984), é a ficção sobre a ficção, isto é, uma ficção que inclui dentro de si um comentário sobre sua própria narrativa e/ou identidade linguística. De acordo com Lopes (2013), trata-se de uma narrativa em dois níveis: o da narração e o do comentário, ou seja, o da reflexão sobre a narração. $O(a)$ autor(a), contudo, abre a possibilidade de comentários metaficcionais para o contexto social e político, não se restringindo às reflexões sobre a natureza linguística e narratológica dos textos e/ou processo do fazer literário. A título de exemplo, poderíamos citar Salman Rushdie, cujo ímpeto metaficcional em muito é voltado para o questionamento das estruturas de poder institucionalizadas, que se impõem socialmente, inclusive através do uso político da religiosidade; e Margaret Atwood, que coloca questionamentos contundentes sobre a relação entre metaficção e gênero.

Já em sua Poética do pós-modernismo: história, teoria, ficção, Hutcheon (1991) alerta que o conceito de metaficção historiográfica se dá por ficções que, além de refletirem sobre a própria escrita, também se caracterizam pela apropriação de personagens e/ou de acontecimentos históricos sob um viés de problematização dos eventos que são tidos como verídicos. Segundo Costa Lima (1989, p. 106), na ficção, o material histórico entra para que 
permita a revisão de seu significado, o que faz com que adquira a possibilidade de "se desdobrar em seu próprio questionamento". Sendo assim, ao se utilizar de fontes históricas, por se tratar de uma ficção e estar no campo do como se (COSTA LIMA, 1987), a metaficção historiográfica abre portas para uma nova interpretação do passado, problematizando-o e colocando em evidência questões antes não levadas em consideração.

De acordo com Jacomel (2008), o que distingue a metaficção historiográfica de um romance histórico - sendo este comprometido apenas em retratar o passado da forma mais fiel possível - é a autorreflexão acarretada pelo questionamento dessas "verdades" consideradas históricas e, por esse motivo, muitas vezes inquestionáveis, haja vista que: "ao problematizar quase tudo o que o romance histórico antes tomava como certo, a metaficção historiográfica desestabiliza as noções admitidas de história e ficção" (HUTCHEON, 1991, p. 159). Sob esse viés, a literatura passa a ter um papel questionador frente aos totalitarismos e às relações de poder na esfera da História, visto que:

O resgate de um acontecimento feito através da obra de arte sempre gera polêmica, pois, nessa "visita" ao passado, podemos descobrir fatos até então não revelados, devido às questões de interesse de grupos conservadores que se sucedem no alto da pirâmide da crítica literária. (JACOMEL, 2008, p. 422).

Abrir espaços para que seja analisada a perspectiva feminina, por exemplo, resulta nessas descobertas, já que por muito tempo a sua visão e vivência da história foram ignoradas, uma vez que por muito tempo as mulheres estiveram fora do relato histórico ou sempre em uma posição marginal. Assim, a partir do século XX, estudos começaram a fortalecer essa tomada de consciência de que por muito tempo a História foi contada "de cima" - e os estudos pós-coloniais e feministas tiveram grande valor nessa revisão de como o passado é narrado -, dado que, conforme explica Jacomel (2008), com o advento da chamada Nova História, o que se entendia como verdade absoluta foi problematizado e contestado. Com isso, inúmeros estudiosos se dedicaram a investigar os discursos marginalizados, e o papel da metaficção historiográfica origina-se exatamente nesse contexto.

Nessa acepção, Hutcheon (1991) explana que a metaficção historiográfica sugere que a verdade e a falsidade não podem ser os pontos de partida para se discutir a ficção, de modo que a metaficção historiográfica defende que só existem "verdades", no plural, e nunca uma só verdade definida. Para a autora, "o que a escrita pós-moderna da história e da literatura nos ensinou é que a ficção e a história são discursos, que ambas constituem sistemas de significação pelos quais damos sentido ao passado" (HUTCHEON, 1991, p. 122), discursos 
esses que podem ser entendidos como formas diferentes de narrar o real acontecido.

Corroborando com essa ideia, para Costa Lima (1987, p. 102), os discursos dos historiadores e dos ficcionistas são entendidos como próximos, porém distintos, uma vez que "se diferenciam tanto pela maneira como suas narrativas se relacionam com o mundo quanto pelo modo como neles atua o narrador". Dessa forma, de acordo com o autor, o discurso ficcional, ao mudar a sua forma de relação com o mundo, também acaba por mudar a sua relação com a verdade.

Ademais, a metaficção historiográfica contrapõe os métodos naturais, ou de senso comum, para distinguir entre o fato histórico e a ficção, por isso:

Ela recusa a visão de que apenas a história tem uma pretensão à verdade, por meio do questionamento da base dessa pretensão na historiografia e por meio da afirmação de que tanto a história como a ficção são discursos, construtos humanos, sistemas de significação, e é a partir dessa identidade que as duas obtêm sua principal pretensão à verdade. (HUTCHEON, 1991, p. 127).

O que se confirma quando paramos para refletir em como muitas vezes as obras ficcionais serviram como documento para a pesquisa histórica, haja vista que por trás de um texto ficcional, seja ele prosaico ou poético, há também um contexto histórico e cultural de escrita, ou mesmo que é retratado no texto. Além disso, a utilização da história através da narrativa literária torna possível que esses eventos sejam interpretados sobre outros vieses ou mesmo problematizados.

\section{CRÍTICA LITERÁRIA FEMINISTA E ESTUDOS DE GÊNERO}

A partir de 1970 os estudos sobre mulheres se intensificaram, em consonância ao fortalecimento do feminismo enquanto movimento político e reivindicatório. Nesse contexto, irrompeu o que conhecemos hoje como crítica literária feminista, que ao criticar a posição fronteiriça ao cânone em que os escritos femininos sempre estiveram, acabou por criar um novo paradigma para as análises literárias. Com isso, foram resgatadas diversas produções femininas esquecidas no tempo, ou mesmo contestadas as representações carregadas de estereótipos em que as mulheres eram construídas na literatura e nas artes em geral por escritores e artistas homens. Atualmente, o viés crítico feminista é utilizado para considerar relações e problemas de gênero presentes em diversas narrativas, o que nos ajuda na compreensão de relações sociais e até mesmo históricas.

Nesse sentido, a crítica literária feminista contemporânea tem como objetivo “[...] 
desmascarar os princípios que têm fundamentado o cânone literário, seus pressupostos ideológicos, seus códigos estéticos e retóricos, tão marcados por preconceitos de cor, de raça, de classe social e de sexo, para, então, desestabilizá-lo, reconstruí-lo" (ZOLIN, 2009, p. 328). Em outras palavras, ao promover a visibilidade das mulheres, esta vertente crítica promove um resgate da produção literária de autoria feminina, revisitando as categorias instituídas da crítica literária tradicional, bem como contestando binarismos e essencialismos referentes ao ser mulher, tendo em vista que as interseccionalidades são necessárias para se compreender diferentes vivências e contextos que as mulheres (sejam elas cis ou transgênero ${ }^{3}$ ) protagonizam. Por isso, aponta-se para a necessidade de se pensar em feminismos plurais, que não tratem as questões femininas como universais.

Elaine Showalter (1994) explica que existem quatro modelos de análise para a crítica feminista, sendo eles: o biológico, o linguístico, o psicanalítico e o cultural. Para a autora, a utilização do enfoque cultural para a análise de produções de autoria feminina torna-se mais satisfatória, uma vez que "uma teoria da cultura incorpora idéias a respeito do corpo, da linguagem e da psique da mulher, mas as interpreta em relação aos contextos sociais nos quais elas ocorrem" (SHOWALTER, 1994, p. 44). Ou seja, o enfoque cultural torna-se mais completo, visto que engloba todas essas questões a respeito da vivência feminina e pelo fato de o próprio gênero ser entendido enquanto uma construção cultural, social, política e simbólica. Por isso, os estudos de gênero são importantes tanto para se analisar a relação das mulheres, escritoras e personagens, na/com a literatura, quanto na sociedade em si, já que na maioria dos casos, esses escritos são representações do que acontece na realidade.

À vista disso, uma teoria cultural, como salienta Showalter (1994), reconhece a existência de diferenças importantes entre as mulheres como escritoras, tais como: classe, raça, nacionalidade e história, que são determinantes literários tão significativos quanto o gênero, além de serem imprescindíveis para não se analisar a experiência feminina como algo universal. Segundo a autora, muitas historiadoras, como a austríaca Gerda Lerner, no campo da história das mulheres, apontam a importância de se examinar a experiência feminina em seus próprios termos, pois:

[...] temos considerado a história somente em termos centrados no homem. Temos perdido as mulheres e suas atividades porque lhes temos colocado

\footnotetext{
${ }^{3}$ Mulheres cisgênero: são aquelas cuja identidade de gênero é correspondente ao gênero que lhe foi atribuído no nascimento. Mulheres transgênero: aquelas que nasceram com o gênero masculino lhes sendo atribuído, mas que se identificam com o feminino. Assim, as críticas literárias feministas também precisam levar em consideração essas diferentes vivências identitárias e as heterogeneidades presentes no "ser mulher", o que pode ser compreendido através dos estudos sobre transfeminismo, por exemplo.
} 
questões históricas inapropriadas às mulheres. Para retificar isso, e para iluminar áreas de escuridão histórica, devemos, por um tempo, focalizarmonos numa indagação centrada na mulher, considerando a possibilidade da existência de uma cultura feminina inserida na cultura geral partilhada por homens e mulheres. A história deve incluir o relato da experiência feminina através do tempo e deveria incluir o desenvolvimento da consciência feminista como aspecto essencial do passado das mulheres. Esta é a tarefa fundamental da história das mulheres. A questão central que ela levanta é: como seria a história se vista através dos olhos das mulheres e ordenada pelos valores que elas definem? (apud SHOWALTER, 1994, p. 45).

A esse respeito, vemos que Carta à rainha louca traz essa possibilidade, de entendermos o período histórico do Brasil colonial através do olhar de Isabel, ordenado pelos seus valores e em como ela entende as questões de gênero e os processos de exploração e subalternização naquela sociedade. Através dela, temos tanto uma visão e experiência pessoal e subjetiva, quanto um panorama social, histórico e cultural do que está ao seu redor.

Para Showalter (1994), um modelo da situação cultural das mulheres é crucial para que se entenda como são percebidas pelo grupo dominante e como se percebem a si mesmas e aos outros. É importante compreender também como não se pode haver escrita ou crítica totalmente fora da estrutura dominante, posto que, como a autora explica, nenhuma publicação é totalmente independente das pressões econômicas e políticas da sociedade dominada pelos homens. Por isso, a escrita de mulheres “é um 'discurso de duas vozes' que personifica sempre as heranças social, literária, cultural tanto do silenciado quanto do dominante" (SHOWALTER, 1994, p. 50). Uma vez que isso ocorre, torna-se possível apreender essas relações de poder de forma abrangente, pois não se compreende a posição de oprimido/silenciado sem antes compreender o porquê da existência de tal opressão, quais os fatores que levam a isso, e quem ou o que contribui para que ela ocorra.

Como elucida Joan Scott (1995, p. 76), enquanto categoria de análise, o uso do termo "gênero" ressalta "todo um sistema de relações que pode incluir o sexo, mas não é diretamente determinado pelo sexo, nem determina diretamente a sexualidade". Nessa perspectiva, compreendemos que os sujeitos não se compõem unicamente pela diferença sexual, mas por diferentes representações culturais ou, como trata Teresa de Lauretis (2019), por um sistema de gênero, em que os conteúdos culturais atuam de acordo com valores e hierarquias sociais, que vão determinar como os sujeitos se comportam em sociedade.

Logo, todos falam a partir de perspectivas tanto de gênero, quanto de raça ou classe, que se tornam aspectos de profunda relevância a serem levados em consideração em uma análise literária. Por isso, o uso da categoria gênero na análise de algum texto ficcional, sempre irá fazer com que ele adquira um significado político, pois, como explica Judith Butler 
(2003, p. 20), tornou-se “impossível separar a noção de 'gênero' das interseções políticas e culturais em que invariavelmente ela é produzida e mantida".

Em razão de todos esses aspectos é que se tornou imperioso criar um paradigma conceitual que abarcasse a experiência da mulher como modelo de interpretação de mundo. Portanto, no ato de ler textos dentro de uma perspectiva feminista, esses estão sendo interpretados em concepções políticas, as quais estão relacionadas com a ideologia e com as relações de poder da/na sociedade em que estão inseridos ou que representam. Como no caso da problematização da posição da mulher no século XVIII, tão marcada pela exploração e violência (principalmente no caso de mulheres negras escravizadas), pelo confinamento no âmbito do lar, pela negação dos espaços públicos e pelo silenciamento.

\section{A CONDIÇÃO FEMININA NO BRASIL COLONIAL DO SÉCULO XVIII}

O Brasil colonial dos Setecentos, período histórico em que se passa Carta à rainha louca (2019), contém muitas peculiaridades relacionadas aos processos de dominação e de subalternização. Isso pode ser compreendido em como por muito tempo na História e na literatura os discursos dos "vencedores" eram os que possuíam relevo e eram narrados. Tanto uma como a outra era escrita e protagonizada por esses homens europeus, que acreditavam e instituíam a ideia de que essa dominação colonialista era uma forma de trazer civilização a povos considerados selvagens, por exemplo.

Para Rios (2018, p. 179), o processo de dominação que caracterizou o colonialismo mostrava a supremacia de "um modelo baseado na hegemonia do homem europeu, branco e cristão sobre o que representava oposto, o Outro, disso culminou na espoliação de povos e suas culturas em prol da imposição da cultura europeia às nações submetidas nesse processo". Isso se refletiu fortemente em grande parte do imaginário ocidental, assegurado pela ideologia patriarcal, raiz da violência e opressão contra o ser feminino.

No caso das mulheres, ocorreu o que Spivak (2010) denomina de dupla subalternização, uma vez que a diferença sexual faz com que estas sejam, enquanto sujeito subalterno, duplamente oprimidas e silenciadas, pois apesar de mulheres e homens serem objetos da historiografia colonialista, "a construção ideológica de gênero mantém a dominação masculina. Se, no contexto da produção colonial, o sujeito subalterno não tem história e não pode falar, o sujeito subalterno feminino está ainda mais profundamente na obscuridade" (SPIVAK, 2010, p. 66-67), em virtude de sofrer ainda mais com repressões e violências, principalmente as mulheres indígenas e escravizadas. 
Por esse motivo, os estudos mais recentes de resgate de produções ou registros femininos desse período, como é o caso dos documentos que serviram como base para a construção ficcional de Maria Valéria Rezende, são importantes para tentar compreender uma voz feminina silenciada e muitas vezes esquecida ou apagada dos arquivos oficiais. Como no caso da personagem Isabel das Santas Virgens, que a escritora denomina como uma "sobrante", palavra que usa para denominar as mulheres que não faziam parte do sistema colonial, isto é, que não podiam servir para o casamento por não terem dote e nem serem escravizadas por possuir a pele branca, colocando-as em uma espécie de não-lugar. Essas mulheres eram descartadas pelo sistema e não tinham muitas opções para sobreviver, assim, eram acolhidas pela mulher cuja carta inspirou a escrita da narrativa.

No Brasil colonial, de acordo com a historiadora Georgina Santos (2020), a presença de mulheres livres nos espaços públicos era conveniente desde que fossem aparições rápidas, como um sinal de recato, ou mesmo quando estavam acompanhadas do pai, do marido ou de um tutor para lhes proteger de "olhares curiosos", pois:

\begin{abstract}
A honra de uma mulher era medida por seu pudor e usada como moeda de troca no mercado matrimonial que, em regra, era assunto dos interesses econômicos e políticos dos homens, e desconsiderava a opinião feminina. $\mathrm{O}$ dote da noiva determinava o status social do pretendente, atraindo ou não para o grupo familiar o capital financeiro e simbólico almejado. (SANTOS, 2020, s./p.).
\end{abstract}

Assim, para as mulheres pobres eram pouquíssimas as opções que lhe sobravam, o que fazia com que muitas acabassem se prostituindo para sobreviver e cuidar dos filhos. Conforme trata Del Priore (1994), as mulheres da elite opunham-se à promiscuidade e à lascívia a que as mulheres da classe subalterna eram submetidas, mesmo sendo algo tão repugnado pela Igreja. Para a historiadora, por estarem deslocadas e frente a um discurso religioso que lhes impunha o imaginário de virtuosas e puras, "as mulheres coloniais são mais filhas de Eva do que de Maria; mergulhadas nas asperezas do trabalho doméstico, ou nos ofícios de rua e da lavoura, acabam por elaborar, mesmo enquanto rascunhos dos modelos eruditos, regras e éticas próprias" (DEL PRIORE, 1994, p. 17-18), o que fez muitas buscarem na vida religiosa mecanismos de resistência às explorações e aos sofrimentos.

Diante disso, muitas delas acabavam por "fundar recolhimentos, instituição que combinava características de orfanato, educandário e convento, para que pudessem dar vazão à sua mística" (SANTOS, 2020, s./p.). Esses lugares serviam como uma forma de amparo, tal como a casa criada por Isabel para essas mulheres sobrantes, num modo de auxiliá-las a não 
precisar vender seus corpos para sobreviver ou passar por outros percalços.

Como continua a autora:

$\mathrm{Na}$ sociedade escravista colonial, a figura feminina era, na esmagadora maioria dos casos, submetida à ordem patriarcal. Mas como se pode apreender de algumas peças do precioso acervo documental do Arquivo Nacional, reagiram aos mandos e abusos do poder masculino, direta ou indiretamente. (SANTOS, 2020, s./p.).

Nesse sentido, buscar formas de resistência era algo que muitas mulheres faziam para suportar o que a sociedade lhes impunha, pois nem todas continuavam em posições passivas e aceitavam sua condição subalternizada. Conforme trata Nunes (2018), a história da vida religiosa feminina no Brasil é marcada por antagonismos entre submissão e transgressão, passividade e criatividade. A pesquisadora também aponta Isabel Maria como exemplo, a personagem histórica que Maria Valéria Rezende encontrou perdida nos registros, que em Minas Novas (Minas Gerais) fundou a Casa de Oração do Vale das Lágrimas, na primeira década do século XVIII: "O recolhimento fora erigido sob a orientação de um padre, arrependido de sua vida pregressa, e era dirigido por Isabel Maria” (2018, p. 485).

Dessa maneira, vemos que Isabel, tanto a histórica quanto a ficcional, utilizou dessas formas de resistência para o acolhimento dessas mulheres, por ver-se perdida em um espaço que se integrava de várias instâncias sociais, econômicas e religiosas contra si, o que fez a personagem ficcional empregar a escrita como uma reivindicação, um resgate da sua memória e a ordenação de seus pensamentos para não cair na armadilha da loucura presumida.

\section{METAFICÇÃO HISTORIOGRÁFICA E GÊNERO: UMA LEITURA DE CARTA À RAINHA LOUCA}

Os estudos relacionados aos entrecruzamentos de história e literatura têm se tornado cada vez mais valiosos na contemporaneidade, sobretudo quando relacionados à metaficção historiográfica - que problematiza o discurso da ideologia dominante - abrindo portas para uma melhor compreensão dos eventos históricos através da ficção. Assim, a partir de uma perspectiva descentralizada, o "marginal" e aquilo que Hutcheon (1991, p. 29) chama de "excêntrico", tanto em termos de classe, de raça, de gênero, de orientação sexual ou de etnia, passam a assumir uma nova importância "à luz do reconhecimento implícito de que na verdade nossa cultura não é o monólito homogêneo que podemos ter presumido".

Nesse sentido, temos no romance de Maria Valéria Rezende uma mulher que endereça uma longa carta escrita entre os anos de 1789, 1790, 1791 e 1792, como são divididos os 
capítulos da narrativa, à rainha D. Maria I, primeira regente de Portugal, fazendo uma reconstrução de sua vida através da escrita, contando, de forma não linear, desde sua infância até o momento em que se vê enclausurada no Recolhimento da Conceição, em Olinda.

Isabel, entre rasuras e lembranças, fala de seus pais, da vida no engenho, das aventuras e problemas que passou junto de Blandina, bem como sobre os outros personagens que se entrelaçam com a sua vida, como o amigo fiel de seu pai, o negro Gregório; as escravas domésticas do engenho, Engrácia e Bernarda; sobre a amizade que faz com Antónia das Frutas e Basília; sobre as moças do convento e as recolhidas na casa em Minas etc.

Ela utiliza-se da escrita para tentar reordenar os seus pensamentos e memórias, pois em muitos trechos as circunstâncias que lhe são impostas a fazem refletir se não está mesmo ficando louca como lhe acusaram, uma vez que percebe as problemáticas de seu tempo de uma forma que não era "natural" a uma mulher, bem como pelo conhecimento adquirido em livros proibidos: "Disso talvez se tenha feito a minha loucura, pois, segundo me dizem, nenhum espírito de mulher, salvo decerto as de linhagem real como Vós, é capaz de suportar o peso do saber" (REZENDE, 2019, p. 16).

A protagonista remete o seu relato à D. Maria I justamente por se tratar de uma mulher, e como ela mesma diz, também sofrer percalços semelhantes aos que a personagem sente enquanto ser feminino, além de esta ser a única forma que encontra para fazer com que a sua verdade seja lida e chegue ao espaço público, uma vez que a Rainha representa essa chegada da mulher ao poder e aos espaços que lhe são negados:

É para que me recordem que agora Vos escrevo, Senhora, pois que em Vós se juntam duas cousas que de raro se podem reunir: o serdes rainha de cetro e coroa, capaz de ordenar e fazer o bom e o justo, acima de todos e quaisquer súditos, de qualquer sexo, que habitem as Vossas terras, e o serdes mulher, capaz de saber o que sofre outra mulher que chama por justiça. (REZENDE, 2019, p. 09).

Como conta, Maria I, apesar de ser uma mulher econômica e socialmente privilegiada, ainda assim sofre das imposições e pressões sociais atreladas ao seu gênero, principalmente relacionada à sua "loucura" que pode ser entendida como reflexo do imaginário que se tinha em relação às mulheres no poder: “[...] que Rainha sois, mas nem por isso sois menos mulher, e sofrer e chorar é o quinhão de todas as filhas de Eva, não obstante sua condição neste mundo" (REZENDE, 2019, p. 10), corroborando com o que trata Del Priore (1994), pois para as mulheres de seu tempo, tendo as instâncias religiosas e sociais moldando como deveriam ser e agir, tinham de sobreviver com a culpa e a dificuldade de serem reprimidas por essa 
visão atrelada ao pecado original cristão.

Isabel continua: "porque em todas as condiçẽes, aqui nessas colônias, em África, nas Índias, na China ou no Reino, no paço real ou na mais pobre aldeia do Vosso Império, estão submetidas às leis dos homens que muito mais duras são para as fêmeas" (REZENDE, 2019, p. 10, rasuras da autora). Podemos perceber nesse trecho que a protagonista rasura essa e várias passagens, rabiscando-as quando acredita ter ido longe demais em sua denúncia, e é nesses fragmentos que revela uma visão muito diferente da que se tinha à época, principalmente vindo de uma mulher pobre que nem mesmo deveria saber ler: "Corria a pena levada por inconvenientes palavras que teimam em escapar do sítio onde trato de tê-las bem atadas no meu espírito - já que delas não me posso livrar - para que não me venham a fugir pela boca e dar razão a quem por louca me toma" (REZENDE, 2019, p. 10). Isabel desculpase pela rasura, no entanto, podemos inferir que há uma intencionalidade por parte dela que tomem conhecimento do que escreve, além de apenas naquele papel lhe ser dada a liberdade de expressar tais palavras.

Como tratado por Faria (2008), uma das principais marcas de uma narrativa metaficcional e uma das fundamentais estratégias que desencadeiam o autoquestionamento presente nelas é a inclusão de um personagem-escritor:

[...] que está escrevendo uma obra ou projetando escrevê-la. Tal estratégia é uma das que mais caracterizam a mímese do processo, ou que a colocam em marcha, na medida em que podemos acompanhar os meandros da criação, podemos observar o personagem-escritor diante de suas dúvidas, de seus impasses, de seu questionamento de como levar a termo o projeto de escrita que se propôs a realizar. (FARIA, 2008, p. 03).

A personagem-escritora Isabel reflete ao longo de todo o romance sobre o próprio ato de escrita, bem como acaba usando o seu sangue para continuar o seu relato quando se vê sem a tinta furtada da biblioteca do Recolhimento, pois:

[...] sinto e sei que a única cousa que me pode manter sã a mente, de sorte que eu não naufrague para sempre no mar encapelado dos meus delírios, é o esforço de ordenar as palavras em meu pensamento e no papel, não importando para nada se são verdadeiras - daquela verdade que querem os inquisidores e os juízes - ou se são apenas a verdade do meu desejo e do meu sonho, da liberdade de pensar, que outros consideram insanidade, mas que teima em medrar no mais recôndito de qualquer mulher. (REZENDE, 2019, p. 51).

Para ela, escrever tornou-se o seu "único socorro nesta vida sem sentido" (REZENDE, 2019, p. 142), assim como mostra que um ofício tão raro - o qual aprendeu ouvindo as aulas 
de sua senhora Blandina com o padre na fazenda em que passou sua infância - acabou se tornando um dos seus meios de sobrevivência. Isabel conta que após cair nas graças de Diogo Lourenço, um malandro galanteador, Blandina entrega-se a ele e acaba grávida. Isso culmina em algo que era comum acontecer com moças burguesas, ou seja, o senhor seu pai, dono do Engenho Paraíso, Dom Afonso de Castro, enviar Blandina, depois de ser deflorada aos 15 anos para um convento: "Sua primogênita já nada mais valia para ele, para seu orgulho e para seus negócios" (REZENDE, 2019, p. 83). Assim, seu pai paga o dote de entrada ao convento para que renuncie à sua herança e se torne monja. Isabel a acompanha nessa jornada para não lhe deixar só, o que a faz trabalhar escrevendo disfarçada de homem:

[...] concebi o ardil de obter trajes adequados e fazer-me homem cada vez que tinha de ir buscar à rua os meios para alimentar e curar minha amada irmã, a quem o pai tudo negava. Fazendo-me de macho, dotado do talento da escrita bela e escorreita, munido de folhas de papel, uma boa pena de metal, um frasco de tinta e lacre furtados do convento, mais alguns sinetes que talhei na madeira, muitas vezes me aventurei pelas ruas e tavernas, a ganhar tostões às custas dos iletrados senhores, sempre necessitados de quem lhes escrevesse cartas, petições, contratos e testamentos, falsos ou verdadeiros, e versos indecentes para presentear suas marafonas. [...] Assim vivi, eu, Joaquim, homem livre. (REZENDE, 2019, p. 114-115).

Com o excerto acima, fica claro que, para sobreviver sem amparo da família ou de um casamento naquela realidade, só era possível para uma mulher como Isabel disfarçando-se de homem, visto que, após a morte de Blandina, Isabel teve de se retirar dos aposentos do convento em que conseguiu se abrigar junto de sua sinhazinha por ter forjado um documento assinado por seu antigo senhor e, assim: "Sentia-me chamada a prosseguir pelo mundo e, talvez, se me fosse dada essa graça, denunciar em grandes letras e alta voz o mal que lhe haviam feito e a quase todas as mulheres desta colônia, a quem nos pudesse socorrer, como faço agora escrevendo a Vossa Majestade" (REZENDE, 2019, p. 114). No entanto, Isabel se descuida e deixa escorrer o sangue de sua menstruação que, ao manchar seus calções masculinos, faz com que todos percebam seu disfarce.

Tal ocorrido faz com que ela se sinta ainda mais perdida naquele contexto opressor, o que a faz criar o local de acolhimento a mulheres em igual situação de não pertencimento e, por conseguinte, a sua prisão no Recolhimento de onde escreve seu relato, e onde por seus gritos e convulsões de recusa ao enclausuramento é tida como louca: "Mas eu, per mim, dige que mais loueas e enganadas pelo Maligno são elas que se deixam prender, maltratar e tosar eomo ovelhas, caladas, que a dulo se submetem. [...] Loucas, tolas, sim, são as que jamais gritam" (REZENDE, 2019, p. 11, rasuras da autora). Isso mostra também como o crime de 
Isabel perante a Coroa estava, principalmente, não em falsificar documentos como fazia enquanto era Joaquim, mas sim no fato de ser uma mulher desobediente, que vai de encontro às regras impostas a praticamente todos os âmbitos daquela sociedade.

Como dito anteriormente, a escrita, escondida em sua cela, era para Isabel a única forma de resistir: “[...] desejei sair desta prisão onde mais nada nem ninguém me cativava a alma e outra vez me pus a buscar penas e tinta com que pudesse escrever, pois não sabia de outro modo para chegar a liberdade senão a força das palavras e essas, por bondade de Deus, eu possuía" (REZENDE, 2019, p. 32). Entretanto, ordenar os seus pensamentos em palavras se torna algo truncado para ela, o que fica perceptível quando lemos o seu relato e vai se tornando possível, aos poucos, compreender a sua jornada: “notai, porém, Majestade, como agora já sou capaz de relatar-Vos, de maneira tão mais ordenada [...] a história que Vos prometi, por ser tão bom remédio para alma e o juízo o simples poder de escrever e ordenar no papel as ideias e as palavras" $(2019$, p. 66).

Os trechos rasurados pela personagem são relevantes para suas reflexões e conclusões sobre o que se passa nas colônias, como podemos ver neste:

[...] pouco importam os que nada temos, como nós as mulheres pobres desta terra, os indígenas massacrados e roubados, os infelizes africanos trazidos à força de suas ricas terras para morrer em meio ao mar oceano de águas revoltas ou ao mar de canas verdes onde poucos sobrevivem mais que uns poucos anos eles que, nas palavras do Pregador António Vieira, só por suas dores já são a mais perfeita imitação de Cristo, saerifieados tos em trabalhos desumanos em nome da evangelização dos pagãos da glória de Vossa Coroa e da riqueza do reino de Portugale seus nobres. (REZENDE, 2019 , p. 67, rasuras da autora).

Nesse e em diversos outros trechos, vemos um discurso que não poderia ser dito com essas mesmas palavras em pesquisas acadêmicas ou nos livros de história, mas que caracteriza de forma incisiva o que acontecia com os indígenas e os africanos escravizados.

Para Caragea (2010, s./p.), nas metaficções historiográficas há "um reconhecimento honesto de que se fala a partir do presente e de que o passado considerado não existe por si próprio, mas é aquele que este presente construiu para o seu próprio uso e em função de desejos e intenções muitas vezes inconfessáveis". Dessa forma, a autora traz, através da ficção, uma forma de refletir sobre o passado por meio dos questionamentos da própria personagem. Ou seja, é uma narrativa em que lemos o relato de Maria Valéria Rezende, através de uma perspectiva feminista, que é o relato de Isabel das Santas Virgens, em uma ficção que se duplifica nela mesma: “Aqui me encontro, Senhora, ou seja lá quem me leia, à beira da minha minúscula janela [...] na esperança de que assim, das palavras [...] possa ainda 
surgir um destino, um norte, uma estrela a guiar-me” (REZENDE, 2019, p. 142).

Destarte, como afirma Gärtner (2006), na condição pós-moderna, especialmente após 1970, tornou-se possível às mulheres escritoras expor os fatos da história sobre a "perspectiva dos vencidos ou da alteridade, e, deste modo, reverter a história tradicional fundando a história do romance histórico de mulheres. A grande marca desses romances é a conquista do espaço pela expressão da voz feminina" (2006, p. 64). Com isso, é possível compreendermos no romance analisado como através da metaficção historiográfica a escrita do romance faz esse revisionismo histórico trazendo a perspectiva de uma mulher marginalizada, contribuindo assim para um melhor entendimento das questões de gênero e das relações de poder no período colonial brasileiro.

\section{CONSIDERAÇÕES FINAIS}

A literatura contemporânea coloca em xeque as noções de real, algo parecido com o que fazem as metaficções historiográficas, em que não se consegue ao certo decifrar quais eventos narrados realmente ocorreram e quais são ficcionais, mas que tampouco se tem a pretensão de se fazer essa distinção. Assim, em Carta à rainha louca (2019), Maria Valéria Rezende se aproveita de uma pesquisa histórica consistente, através de documentos de arquivos oficiais, mas foi utilizando-se da ficção que deu novos rumos a esses eventos ocorridos, trazendo uma personagem consciente das problemáticas de seu tempo.

Temos no romance uma perspectiva descentralizada, atrelada a noções de gênero e de classe, que singularizam a perspectiva em que é narrado. De acordo com Hutcheon (1991): “[a] ficção pós-moderna sugere que reescrever ou reapresentar o passado na ficção e na história é - em ambos os casos - revelá-lo ao presente, impedi-lo de ser conclusivo e teleológico" (HUTCHEON, 1991, p. 147). Ou seja, a metaficção historiográfica torna possível percebermos as brechas deixadas pelo discurso histórico, o que faz com que se perceba como com essa volta ao passado através da ficção é possível destrinchar eventos que já foram revisitados e que se acreditava estarem concluídas as questões em torno deles.

Ademais, compreendemos como em tais narrativas, essa volta ao passado não é um retorno nostálgico, mas, como trata Hutcheon (1991, p. 20): “é uma reavaliação crítica, um diálogo irônico com o passado da arte e da sociedade [...] Suas formas estéticas e suas formações sociais são problematizadas pela reflexão crítica”. E, com isso, o leitor passa a ter um papel reflexivo perante os eventos que são trazidos, uma vez que ao tentar apreender o passado, "nós não somos um receptáculo passivo do discurso que pretende revelá-lo, mas 
participamos ativamente na releitura/reescrita da história" (CARAGEA, 2010, s./p.). Como no caso da História das mulheres que foram muitas vezes imaginadas e representadas, ao invés de serem descritas ou contadas por elas mesmas. Desse modo, as obras contemporâneas que fazem uma retomada ao passado e trazem a visão de sujeitos marginalizados mostram a sua importância não só literária como também social.

Portanto, nossa leitura do romance aponta que através do relato da protagonistaescritora Isabel das Santas Virgens, Maria Valéria Rezende mostra a voz e a perspectiva de uma mulher do século XVIII, problematizando a sua espécie de não-lugar em um contexto colonial, pois, sendo mulher e pobre, os caminhos para sobreviver naquela sociedade foram árduos. No romance, Isabel ajuda a denunciar não só o que fizeram a ela, como prendê-la injustamente e acusá-la louca - algo que era muito comum acontecer com mulheres desviantes -, mas também a apontar as mazelas que sofriam os que não possuíam um lugar na colônia, a exemplo de mulheres brancas não aceitas para o matrimônio, que com a ajuda de Isabel formam um lugar de acolhimento e sororidade.

Fica evidente que as questões abordadas pela autora se mostram ainda muito pertinentes de serem analisadas na contemporaneidade, tanto para se ter uma visão mais ampla do passado, como, principalmente, para compreender e refletir sobre as desigualdades e violências contra as mulheres que ainda persistem. Vemos, então, que as questões sociais relacionadas ao feminino do passado ainda se entrelaçam com as problemáticas de nosso tempo, pois muito do que ocorre hoje é fruto da subjugação histórica que mulheres e pessoas colocadas à margem sofreram. Nesse sentido, a partir de uma perspectiva feminista, torna-se possível não só evidenciar esses eventos, como também trazer reflexões acerca deles, a fim de buscar formas de mudar o presente.

\section{REFERENCIAS}

AZZI, Riolando; REZENDE, Maria Valéria V. A vida religiosa feminina no Brasil colonial. In: AZZI, Riolando (Org.). A vida religiosa no Brasil. Enfoques históricos. São Paulo: Paulinas, 1983. p. 24-60.

BUTLER, Judith. Problemas de gênero: feminismo e subversão da identidade. Rio de Janeiro: Civilização Brasileira, 2003.

CARAGEA, Mioara. Metaficção historiográfica. In: CEIA, Carlos (Org.). E-Dicionário de termos literários. 2010. Disponível em: https://edtl.fcsh.unl.pt/encyclopedia/metaficcaohistoriografica/. Acesso em: 14 abr. 2021. 
COSTA LIMA, Luiz. Narrativa e ficção. In: COSTA LIMA, Luiz. A aguarrás do tempo: estudos sobre a narrativa. Rio de Janeiro: Rocco, 1989. p. 68-121.

DEL PRIORE, Mary. A mulher na história do Brasil. São Paulo: Contexto, 1994.

FARIA, Zênia de. A metaficção revisitada: uma introdução. Signótica, v. 24, n. 1, p. 237-251, jan./jun., 2012.

FARIA, Zênia de. Sobre a metaficção e outras estratégias narrativas em A rainha dos cárceres da Grécia. In: XI Congresso Internacional da ABRALIC - Tessituras, Interações, Convergências, 2008, USP - São Paulo, Brasil, Anais... p. 01-08. Disponível em: https://abralic.org.br/eventos/cong2008/AnaisOnline/simposios/pdf/066/ZENIA FARIA.pdf Acesso em: 10 dez. 2020.

GÄRTNER, Mariléia. Mulheres contando história de mulheres: o romance histórico brasileiro contemporâneo de autoria feminina. 2006. 215 f. Tese (Doutorado em Letras) Universidade Estadual Paulista, Faculdade de Ciências e Letras de Assis, São Paulo, 2006.

HUTCHEON, Linda. Narcissistic narrative: the metafictional paradox. 2. ed. New York: Methuen, 1984.

HUTCHEON, Linda. Poética do pós-modernismo: história, teoria, ficção. Tradução: Ricardo Cruz. Rio de Janeiro: Imago Editora, 1991.

JACOMEL, Mirele Carolina Werneque. Tecendo o avesso da história pela metaficção historiográfica. Uniletras, Ponta Grossa, v. 30, n. 2, p. 421-460, jul./dez., 2008.

KRAUSE, Gustavo Bernardo. O livro da metaficção. Rio de Janeiro: Tinta Negra Bazar Editorial, 2010.

LAURETIS, Teresa de. A tecnologia do gênero. In: HOLLANDA, Heloísa Buarque de. (Org.). Pensamento feminista: conceitos fundamentais. Rio de Janeiro: Bazar do Tempo, 2019. p. 121-155.

LOPES, Sebastião Alves Teixeira. Unforgivable words: the social place of writers and of literary texts in Salman Rushdie's The satanic verses and Haroun and the sea of stories. West East Journal of Social Sciences, v. 2, n. 3, p. 15-20, dez., 2013.

NUNES, Maria José Rosado. Freiras no Brasil. In: DEL PRIORE, Mary (Org.). História das mulheres no Brasil. 10. ed. São Paulo: Contexto, 2018. p. 482-509.

PIACESKI, Daiana Patrícia F. P. Maria Valéria Rezende: colorindo invisíveis por meio da literatura. Revista Crioula - Dissidências de Gênero e Sexualidade nas Literaturas de Língua Portuguesa. n. 24, p. 250-267, jul./dez., 2019.

REZENDE, Maria Valéria. Carta à rainha louca. Rio de Janeiro: Alfaguara, 2019.

RIOS, Dinameire Oliveira Carneiro. Vozes dissonantes: a representação da mulher colonial no novo romance histórico. 2018. 221 f. Tese (Doutorado em Literatura e Cultura) Universidade Federal da Bahia, Salvador, 2018. 
SANTOS, Georgina. Papéis passados: a história das mulheres a partir da documentação arquivística. O Arquivo Nacional e a História Luso-Brasileira - Mulheres na colônia. 2020.

http://www.historiacolonial.arquivonacional.gov.br/index.php?option=com content\&view=art icle\&id=5347\&Itemid=460 Acesso em: 15 abr. 2021.

SCHØLLHAMMER, Karl Erik. Ficção brasileira contemporânea. Rio de Janeiro: Civilização Brasileira, 2009.

SCOTT, Joan. Gênero: uma categoria útil para a análise histórica. Educação \& Realidade, v. 20, n. 2, p. 71-99, jul./dez., 1995.

SHOWALTER, Elaine. A crítica feminista no território selvagem. Tradução: Deise Amaral. In: HOLLANDA, Heloísa Buarque de (Org.). Tendências e impasses: o feminismo como crítica da cultura. Rio de Janeiro: Rocco, 1994. p. 23-57.

SPIVAK, Gayatri. Pode o subalterno falar? Tradução: Sandra Regina Goular Almeida, Marcos Pereira Feitosa, André Pereira Feitosa. Belo Horizonte: UFMG, 2010.

ZOLIN, Lúcia Osana. Literatura de autoria feminina. In: BONNICI, Thomas; ZOLIN, Lúcia Osana (Orgs.). Teoria literária: abordagens históricas e tendências contemporâneas. 3. ed. Maringá: Eduem, 2009. p. 327-336. 